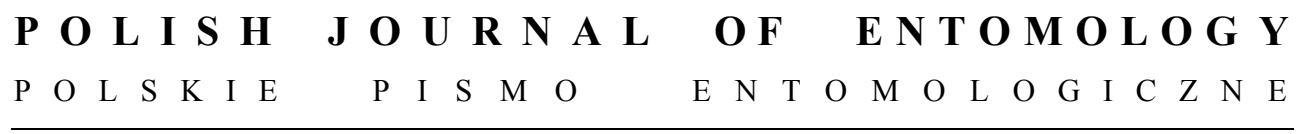

VOL. 81: $321-330$

Gdańsk

31 December 2012

DOI: $10.2478 / \mathrm{v} 10200-012-0012-0$

\title{
Rare European donacid beetle Macroplea appendiculata PANZER, 1794 \\ (Coleoptera: Chrysomelidae: Donaciinae) common in Polish fish ponds
}

\author{
RADOSŁAW ŚCIBIOR ${ }^{1}$, ROBERT STRYJECKI ${ }^{1}$, MAREK NIEOCZYM ${ }^{1}$, JAN BEZDĚK ${ }^{2}$ \\ ${ }^{1}$ Department of Zoology, Animal Ecology and Wildlife Management, \\ University of Life Sciences in Lublin, Akademicka 13, 20-950 Lublin, Poland, \\ corresponding author's e-mail: radoslaw.scibior@up.lublin.pl; \\ ${ }^{2}$ Department of Zoology, Mendel University, Zemědělská 1, 61300 Brno, Czech Republic, \\ e-mail: bezdek@mendelu.cz
}

\begin{abstract}
Macroplea appendiculata PANZER, 1794 is an extremely rare species in Poland and Europe. This paper provides new data on the ecology of this species. 24 specimens of M. appendiculata were collected in fish ponds at Samoklęski. This beetle was caught mainly with active traps placed on the bottom, but it was not found in traps set just below the water surface. The data show that $M$. appendiculata is a typical benthic organism, moving vertically to only a small extent. The low rate of metabolism allows this beetle to inhabit waters of varied, as well as low, oxygen content. The occurrence of the most numerous population of $M$. appendiculata in fish ponds, currently known in Poland, indicates the crucial role of this kind of water body as a habitat for this species.
\end{abstract}

KEY WORDS: Macroplea appendiculata, fish ponds, habitat preferences, ecology, Poland.

\section{INTRODUCTION}

The small Palaearctic genus Macroplea SAMOUelLe, 1891 encompasses only 7 species (SILFVERBERG 2010, LOU at al. 2011); three of them (except for M. huaxiensis LoU \& LIANG, 2011, M. japana (JACOBY, 1885), M. ranina LOU \& YU, 2011 and M. skomorokhovi MEDVEDEV, 2006) occur in Europe, of which two (M. mutica FABRICIUS, 1792 and M. appendiculata) are also present in Poland (WARCHAŁOWSKI 1985, ASKEVOLD 
1990, SiLfVERBERG 2010). The genus Macroplea includes the smallest and entirely aquatic (hydrophilous or almost hydrobiontic) representatives of the family Chrysomelidae living on submerged plants or at the bottom. The Polish species of Macroplea are ecologically associated with freshwaters (M. appendiculata) or brackish waters (M. mutica inhabits the Baltic Sea). Both of these species are entirely adapted to an aquatic life and invariably remain under water at the bottom or on submerged macrophytes. M. appendiculata and M. mutica are very closely related ecologically (WARCHAŁOWSKI 1985); at the same time they comprise a genetic sister group with a relatedness of ca 5-6\%. This means that both species are relatively young and diverged approximately about 2.5 million years ago from temperate Europe. At present they occupy diverse niches, mainly with different salinities (KÖLSCH et al. 2006). In Poland, both species are easily recognizable from the morphology of the male copulatory apparatus and a few other morphological or habitat differences (WARChaŁOWSKi 1985, LOU et al. 2011). Protected by law in Poland, these two species are the only protected representatives of Chrysomelidae in the country. M. appendiculata is regarded as endangered (category - 2) in Germany (GEISER 1998) and it is critically endangered also in the Czech Republic (STREJČEK \& BEZDĚK 2005) and Poland (PAWŁOWSKI et al. 2002). This beetle appears to be very rare practically throughout its European distribution range. Recently, we have acquired the first reliable data on this species for Poland since the 1970s. In the last decade it has been collected at a number of study sites in south-eastern Poland (ŚCIBIOR et al. 2008), the Pomeranian Lake District and the Małopolska Upland (BUCZYŃSKI 2012, BUCZYŃSKI et al. 2012, in press).

The same applies to data from the countries bordering Poland or areas situated not far away. From the Czech Republic there are only older data from Moravia (Č́žžEK 1987) and Bohemia (KANTNER \& SNÍŽEK 1991, DOLEŽAL 1995), together with some newer information from Bohemia (KŘIVAN 2004, BEZDĚK - unpublished data). There are no data on the occurrence of this species in Slovakia in the catalogue of Palaearctic beetles (SILFVERBERG 2010), but there is one old single specimen from this area, preserved in the National Museum in Prague (BEZDĚK - unpublished data). Although this species has not been recorded in Latvia (BUKEJS 2010), it has been found in Belarus (LOPATIN \& Nesterova 2005) and Lithuania (TAMUtis et al. 2011). From several central European countries like Austria (GEISER 2004), Hungary (ROZNER 1996, VIG 2003) or the European part of Russia (ROMANTSOV 2007) we have only older - insufficient or unconfirmed - data on this species. Detailed information on the present status of $M$. appendiculata can be found in numerous papers from Germany (MOHR 1985, KROKER 1986, GÜRLICH 1992, HEINIG \& SCHÖLLER 1997, KÖHLER \& KLAUSNITZER 1998, KÖLSCH et al. 2006).

The main objective of the present authors was to obtain relatively detailed and new information on the ecology of this species during studies on the micropopulation inhabiting fish ponds in the Lublin Region. 


\section{STUDY AREA}

The studies were conducted in the complex of fish ponds (carp ponds) situated in the village of Samoklęski (Lublin Province, Kamionka commune, Lubartów district) (N: $\left.51^{\circ} 26^{\prime} 7.41^{\prime \prime}, \mathrm{E}: 22^{\circ} 25^{\prime} 57.33^{\prime \prime}\right)$. The ponds are situated in the Lubartów Upland, which is part of the South Podlasie Lowland (KONDRACKI 2002). The area covers the central part of the interfluve of the Rivers Vistula and Bug (MichalcZYK \& WILGAT 2008).

The complex at Samokleski comprises 33 ponds with a total area of 185.5 ha. The areas of particular ponds range from 0.8 to 13.5 ha, and the maximum depth is $2 \mathrm{~m}$. The ponds are supplied by the River Minina, a left-bank tributary of the River Wieprz. The complex of ponds was established at the broadest point in the Minina valley. An additional water resource supplying the ponds is a left-bank tributary of the Minina, referred to as the Pracz in drainage studies (MiCHALCZYK \& WILGAT 1998).

The ponds are managed in the standard manner: autumn catches, fish feeding, fertilization, controlled water levels in ponds, mowing and burning of swamps. Water does not flow through the ponds of the complex; although they are carp ponds, other fish like pike, catfish, tench and grass carp are also farmed there (NIEOCZYM 2003).

\section{MATERIAL AND METHODS}

The macroinvertebrate studies of the carp ponds on the Samoklęski fish farm were conducted in 2004-2007 and 2010. Samples of bottom and phytophilous macrofauna were taken from April till July. Apart from taking biological samples, the basic physical and chemical parameters of the waters were measured, i.e. temperature, $\mathrm{pH}$, electrolytic conductivity, dissolved oxygen and oxygen saturation.

In 2004-2007, macroinvertebrates were collected using active traps placed on the bottom and at $0.5 \mathrm{~m}$ depth, as well as with a Kajak sediment core sampler. In 2010 macroinvertebrates were caught using the following three types of equipment: 1) ten active traps of 1.01 volume, placed at the bottom of every pond and exposed for 24 hours, after which they were removed and the trapped animals emptied;2) ten 4.01 active traps placed just below the water surface in every pond; 3 ) a hydrobiological sampler with a $25 \mathrm{~cm}$ square frame and a $0.25 \mathrm{~mm}$ mesh net; these samples were collected at a distance of $10 \mathrm{~m}$ from the transect where the active traps $(1.0$ and 4.01$)$ were exposed. Given that the sampling distance was $10 \mathrm{~m}$ and that the length of the sampler side was $0.25 \mathrm{~m}$, one sample covered ca $2.5 \mathrm{~m}^{2}$ of the bottom area.

\section{RESULTS AND DISCUSSION}

24 specimens of Macroplea appendiculata were caught in the Samoklęski fish ponds. This number can be considered high due to the extreme rarity of this species. At the same 
time it is the largest number of individuals caught in Poland in such a small area. Only imaginal stages were found in the samples. This leaf beetle was collected in every month of the studies, from April till July. Most specimens (13) were found in May, the least (1) in July (see Table).

22 specimens of $M$. appendiculata were caught in the 1.01 active traps, and 2 in the Kajak sediment core sampler. None were found in the samples from the 4.01 traps or in the hydrobiological sampler. Most specimens were found in the traps placed at the bottom of the ponds (18 ind.); 2 individuals were caught in the traps placed at $0.5 \mathrm{~m}$ depth (see Table).

The water inhabited by $M$. appendiculata had the following physical and chemical parameters: temperature $-16.7-23.2^{\circ} \mathrm{C} ; \mathrm{pH}-6.28-9.03$; conductivity $-396-495 \mu \mathrm{S} / \mathrm{cm}$; dissolved oxygen $-4.22-8.10 \mathrm{mg} \mathrm{O}_{2} / 1$; oxygen saturation $-48.3-88.0 \%$.

Most specimens of M. appendiculata (8) were collected in the Pszenny fish pond, a small pond with an area of 2.5 ha. The swamp belt, which covered ca $17 \%$ of the pond area, was dominated by Phragmites australis, with a large proportion of Schoenoplectus lacustris and Typha sp. Apart from the belt of shore vegetation, there were also patches of Potamogeton lucens. The bottom was hard, sandy, with a small fraction of mud by the pond edges. Oxygen conditions in this pond were rather poor (see Table).

Macroplea appendiculata was quite numerous in the small (2.3 ha) Bilsk fish pond ( 7 ind.). The swamp, covering ca $26 \%$ of the pond's area, was formed by Phragmites australis and Schoenoplectus lacustris. There were no macrophytes (elodeids) other than the belt of shore vegetation. The bottom was muddy, with a considerable thickness of sediments. In this pond, dissolved oxygen and oxygen saturation levels were distinctly higher than in the other ponds. The considerable numbers of $M$. appendiculata in waters of varied oxygen conditions shows that neither dissolved oxygen nor oxygen saturation are factors significantly influencing the occurrence of this beetle species. This may be due to the specific way this beetle breathes - the larva takes oxygen from the aerenchyma of its host plants (WARCHAŁOWSKI 1985), whereas the imago takes oxygen directly from the water, although it is not strongly dependent on the water's oxygen content. It is not very active, so its energy requirements are not that high (the lack of wings and wing muscles, low metabolic rate). It also seems that $M$. appendiculata has no clear preferences for a particular kind of a bottom - it is equally numerous on a muddy or sandy bottom. The catching of the largest number of $M$. appendiculata individuals in one-litre traps placed on the bottom of fish ponds (18 ind.) and in the Kajak sediment core sampler $(2$ ind.) indicates that this beetle is mainly associated with the benthic zone of water bodies. Two individuals were found in active traps placed at $0.5 \mathrm{~m}$ depth, but none were caught in the 4-liters active traps deployed just below the water surface. M. appendiculata must therefore be included in the benthos, but not in the nectobenthos, which consists of actively flying insects penetrating to 
the bottom of water bodies (e.g. water bugs Corixidae, Noronecta sp. and the beetles from the family Dytiscidae, Hydrophilidae and Haliplidae).

In Lublin Province $M$. appendiculata had been recorded earlier from the fish ponds at Samoklęski and Lake Skomielno (ŚCIBIOR at al. 2008). At Samoklęski 2 individuals were found in the Siedlecki pond in active traps at $0.5 \mathrm{~m}$ depth, while in the shallow littoral of Lake Skomielno one individual was caught in a hydrobiological net. Interesting data about the present distribution of M. appendiculata in Poland is provided by BUCZYŃSKI (2012), who reported this species from running waters in the Pomeranian Lake District (3 imagines in the River Płonia) and in the vicinity of Zamość in a tributary of the River Wolbórka (also 3 imagines). In the River Płonia M. appendiculata was collected below its outflow from Lake Miedwie, hence its presence there will have been due to larval drift (BUCZYŃSKI 2012, in press). In addition, this chrysomelid beetle has recently been found for the first time in the Kashubian Lake District, in a peat bog water body, which has not yet been recorded as a habitat of this species in Poland (BUCZYŃSKI et al. 2012, in press). The principal and natural environments of this species are large water bodies with stagnant water (lakes, ponds) supporting a few common plant species from the genera Myriophyllum or Potamogeton. For example, it was collected in July in the Russian Lake Ladoga, the largest lake in Europe (ROMANTSOV 2007).

Table. A complete list of the specimens collected and the habitats in which they occurred.

\begin{tabular}{|c|c|c|c|c|c|c|c|c|}
\hline 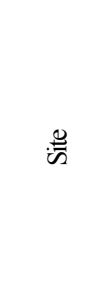 & 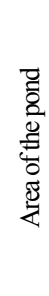 & 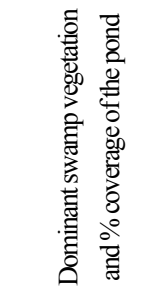 & 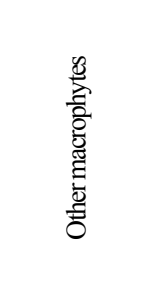 & 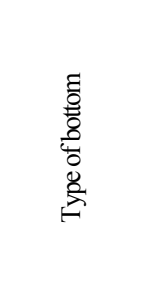 & 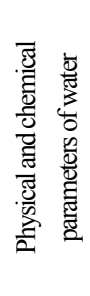 & 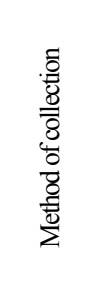 & صّँّ & 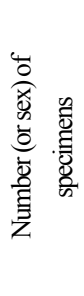 \\
\hline $\begin{array}{l}\text { Bilsk } \\
\text { Pond }\end{array}$ & $\begin{array}{l}2.3 \\
\text { ha }\end{array}$ & $\begin{array}{c}\text { Phragmites } \\
\text { australis, }\end{array}$ & $\begin{array}{c}\text { Batrachium } \\
\text { aquatile, }\end{array}$ & $\begin{array}{c}\text { muddy, } \\
\text { with }\end{array}$ & - & \multirow[b]{2}{*}{$\begin{array}{l}1.0 \text { litre } \\
\text { active } \\
\text { trap } \\
\text { placed } \\
\text { on the } \\
\text { bottom }\end{array}$} & $\begin{array}{l}25.04 . \\
2004\end{array}$ & $1 \mathrm{ex}$. \\
\hline $\begin{array}{c}\mathrm{N}: 51^{\circ} 25^{\prime} \\
51.34^{\prime \prime} \\
\mathrm{E}: 22^{\circ} 25^{\prime} \\
14.4^{\prime \prime}\end{array}$ & & $\begin{array}{c}\text { Schoenoplectus } \\
\text { lacustris, } \\
26 \%\end{array}$ & $\begin{array}{l}\text { Potamogeton } \\
\text { lucens, } \\
\text { Myriophyllum } \\
\text { spicatum, } \\
\text { Polygonum } \\
\text { amphibium }\end{array}$ & $\begin{array}{l}\text { considerable } \\
\text { thickness of } \\
\text { sediments }\end{array}$ & - & & $\begin{array}{l}23.04 . \\
2005\end{array}$ & 1 우 \\
\hline
\end{tabular}




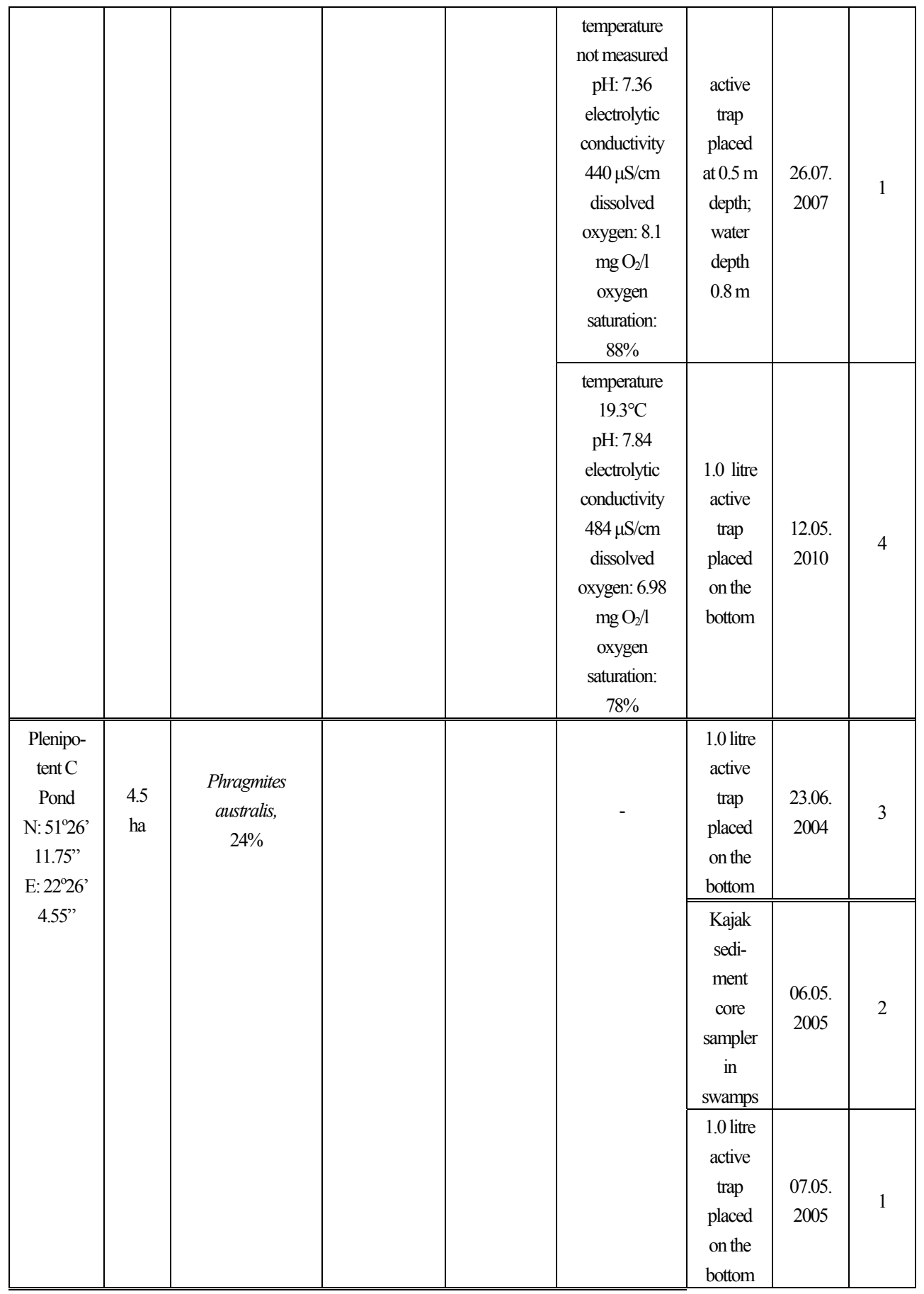




\begin{tabular}{|c|c|c|c|c|c|c|c|c|}
\hline & & & & & & $\begin{array}{c}1.0 \text { litre } \\
\text { active } \\
\text { trap }\end{array}$ & $\begin{array}{l}22.06 . \\
2005\end{array}$ & $1 \widehat{\jmath}$ \\
\hline \multirow[b]{3}{*}{$\begin{array}{c}\text { Pszenny } \\
\text { Pond } \\
\text { N: } 51^{\circ} 25^{\prime} \\
54.55^{\prime \prime} \\
\text { E: } 22^{\circ} 25^{\prime} \\
4.74^{\prime \prime}\end{array}$} & \multirow[b]{3}{*}{$\begin{array}{l}2.5 \\
\text { ha }\end{array}$} & \multirow[b]{3}{*}{$\begin{array}{c}\text { Phragmites } \\
\text { australis, } \\
\text { Schoenoplectus } \\
\text { lacustris, } \\
\text { Typha sp., 17\% }\end{array}$} & \multirow[b]{3}{*}{$\begin{array}{c}\text { Potamogeton } \\
\text { lucens }\end{array}$} & \multirow[b]{3}{*}{$\begin{array}{l}\text { hard, sandy, } \\
\text { with some } \\
\text { mud near } \\
\text { the shores }\end{array}$} & - & & $\begin{array}{c}25.04 . \\
2004\end{array}$ & 3 \\
\hline & & & & & - & & $\begin{array}{l}06.05 . \\
2004\end{array}$ & 3 \\
\hline & & & & & $\begin{array}{c}\text { Temperature } \\
19.9^{\circ} \mathrm{C} \\
\mathrm{pH}: 7.66 \\
\text { electrolytic } \\
\text { conductivity: } \\
418 \mu \mathrm{S} / \mathrm{cm} \\
\text { dissolved } \\
\text { oxygen: } 4.66 \\
\text { mg } \mathrm{O}_{2} / 1 \\
\text { oxygen } \\
\text { saturation: } \\
52 \%\end{array}$ & $\begin{array}{l}1.0 \text { litre } \\
\text { active } \\
\text { trap } \\
\text { placed } \\
\text { on the } \\
\text { bottom }\end{array}$ & $\begin{array}{l}12.05 . \\
2010\end{array}$ & 2 \\
\hline $\begin{array}{c}\text { Szopa } \\
\text { Pond } \\
\text { N: } 51^{\circ} 26^{\prime} \\
6.33^{\prime \prime} \\
\text { E: } 22^{\circ} 26^{\prime} \\
20.68^{\prime \prime}\end{array}$ & $\begin{array}{l}9.2 \\
\text { ha }\end{array}$ & $\begin{array}{c}\text { Typha } \\
\text { angustifolia, } \\
\text { Phragmites } \\
\text { australis, 18\% }\end{array}$ & $\begin{array}{l}\text { Polygonum } \\
\text { amphibium }\end{array}$ & $\begin{array}{l}\text { sandy; no } \\
\text { muddy } \\
\text { fraction; no } \\
\text { vegetation }\end{array}$ & $\begin{array}{c}\text { temperature: } \\
\text { not measured } \\
\mathrm{pH}: 9,03 \\
\text { electrolytic } \\
\text { conductivity: } \\
386 \mu \mathrm{S} / \mathrm{cm} \\
\text { dissolved } \\
\text { oxygen: } 10.5 \\
\text { mg } \mathrm{O}_{2} / 1 \\
\text { oxygen } \\
\text { saturation: } \\
130 \%\end{array}$ & $\begin{array}{l}\text { active } \\
\text { trap } \\
\text { placed } \\
\text { at } 0.5 \mathrm{~m} \\
\text { depth; } \\
\text { water } \\
\text { depth } \\
0.9 \mathrm{~m}\end{array}$ & $\begin{array}{l}27.06 . \\
2006\end{array}$ & 1 우 \\
\hline $\begin{array}{c}\text { Oaza } \\
\text { or Łucja- } \\
\text { nów } \\
\text { Pond }\end{array}$ & & & & & & $\begin{array}{c}1.0 \text { litre } \\
\text { active } \\
\text { trap }\end{array}$ & $\begin{array}{l}\text { May } \\
2010\end{array}$ & 1 \\
\hline
\end{tabular}

\section{CONCLUSIONS}

In Poland, as in Central Europe, Macroplea appendiculata is a beetle species not found in large numbers, and often at single sites within its range of the occurrence. So far, the more extensive studies on populations of $M$. appendiculata have concentrated on the 
influence of the salinity and oxygen saturation of a water body on the occurrence and numbers of this species, while earlier papers focused on the physical occurrence of individuals in water bodies, giving just a cursory description of the water body in question. However, the vast majority of published information about this species consists of short notes of a faunistic character or review papers reporting its occurrence in a particular water body. The new Polish sites mentioned in this paper extend our knowledge of this species as well as its biotic and abiotic habitat preferences. Despite the many papers on the subject, detailed data on the biology of this beetle is still scarce. We have most likely compiled a practically complete list of host plant species on which either imagines or larvae of M. appendiculata live, breed and even feed; but the great rarity or absence of this species in water bodies shows that there must be some further, rather poorly understood factors determining the suitability of a habitat for this species. Our observations and literature data show that in many cases neither the character of a water body (natural or anthropogenic) nor the high content of organic compounds (eutrophication, for example) are strict limiting factors for the occurrence of this species.

It is interesting that the largest population of Macroplea appendiculata in Poland was found in anthropogenic water bodies like fish ponds, not in natural ones, a fact that is indicative of the crucial role of this kind of water body as a habitat for this species.

\section{REFERENCES}

ASKEVOLD I.S. 1990. Reconstructed phylogeny and reclassification of the genera of Donaciinae (Coleoptera: Chrysomelidae). Quaestiones Entomologicae 26: 601-664.

BUCZYŃSKI P. 2012. New records of Macroplea appendiculata (PANZER, 1794) (Coleoptera: Chrysomelidae) in Poland. Wiadomości Entomologiczne 31: 126-127.

Buczyński P., Ciechanowski M., KARASEK T. 2012. (in press). Torfowisko w Martenkach (Pojezierze Wschodniopomorskie) - interesująca ostoja entomofauny wodnej. Chrońmy Przyrodę Ojczystą.

BukeJS A. 2010. On Latvian Donaciinae KIRBY, 1837 (Coleoptera: Chrysomelidae). Acta Biologica Universitatis Daugavpiliensis 10: 115-126.

ČížEK P. 1987. Př́íspěvek k poznání fauny brouků čeledi Chrysomelidae v Československu. Zprávy Československé Společnosti Entomologické 23: 59-63.

DOLEŽAL Z. 1995. Vodomilné mandelinky - rákosníčci v západních Čechách. Živa 43: 28-29.

GEISER R. 1998. Rote Liste der Käfer (Coleoptera) excl. Laufkäfer (Carabidae). [In:] BinOT M., BLESS R., Boye P., Gruttke M. \& Pretscher P. (eds). Rote Liste gefährdeter Tiere Deutschlands. Schriftenreihe für Landschaftspflege und Naturschutz, Heft 55. Bonn-Bad Godesberg: Bundesamt für Naturschutz.

GEISER E. 2004. Chrysomelidae (Insecta: Coleoptera). Checklisten der Fauna Österreichs. 1. Biosystematics and Ecology Series 22: 1-30.

GÜRLICH S. 1992. Die Blattkäfer (Coleoptera: Chrysomelidae) des Niederelbegebietes und SchleswigHolstein. Verhandlungen des Vereins für Naturwissenschaftliche Heimatforschung zu Hamburg. V. 40: 1-78. 
HeINIG U., SchöLleR M. 1997. Liste der Blatt- und Samenkäfer von Berlin und Brandenburg (Coleoptera: Chrysomelidae, Bruchidae). Novius 21: 460-497.

KANTNER F., SNí̌EK M. 1991. Př́íspěvek k poznání mandelinky Macroplea appendiculata (PANZ.) (Coleoptera, Chrysomelidae, Donaciinae). (A contribution to the knowledge on the leaf-beetle Macroplea appendiculata (PANZ.) (Coleoptera, Chrysomelidae, Donaciinae). Zprávy Československé Společnosti Entomologické 27: 56-57.

KONDRACKI J. 2002. Geografia regionalna Polski. Wydawnictwo Naukowe PWN, Warszawa, 450 pp.

KÖHLER F., KLAusnitzer B. 1998. Verzeichnis der Käfer Deutschlands. Entomologische Nachrichten und Berichte (Dresden) Beiheft 4: 1-185.

Kölsch G., Biström O., Pedersen B.V. 2006. Species delimitation in the leaf beetle genus Macroplea (Coleoptera, Chrysomelidae) based on mitochondrial DNA, and phylogeographic considerations. Insect Systematics and Evolution 37: 467-479.

KŘIVAN V. 2004. Třeboňsko - ráj rákosníčků. Ochrana Př́rody 59: 13-14.

KROKER H. 1986. Coleoptera Westfalica: Familia Chrysomelidae (ohne Unterfamilie Alticinae). Abhandlungen aus dem Westfälischen Museum für Naturkunde 48: 1-121.

MichalCZYK Z., WiLgat T. 1998. Stosunki wodne Lubelszczyzny. Wydawnictwo UMCS, Lublin, pp.: 167.

Michalczyk Z., Wilgat T. 2008. Wody. [In:] Uziak S., TURSKi R. (eds). Środowisko przyrodnicze Lubelszczyzny. Lubelskie Towarzystwo Naukowe. Lublin, pp.: 113-216.

MoHR K.H. 1985. Beiträge zur Insektenfauna der DDR: Coleoptera - Chrysomelidae: Donaciinae, Orsodacninae, Criocerinae, Clythrinae. Beiträge zur Entomologie 35: 219-262.

NiEOCZYM M. 2003. Awifauna stawów rybnych w Samoklęskach w latach 2001-2002. Praca magisterska. Wydział Biologii i Nauk o Ziemi, UMCS Lublin.

LOPATIN I.K., NESTEROVA O.L. 2005. Insecta of Byelarus: leaf-beetles (Coleoptera, Chrysomelidae). UU "Technoprint", Minsk, pp.: 294.

Lou Q., Yu P., Liang H. 2011. Two new species of Macroplea SAmouelle (Coleoptera: Chrysomelidae: Donaciinae) from China, with a key to all known species. Zootaxa 3003: 1-21.

PawŁowski J., Kubisz D., Mazur M. 2002. Coleoptera - Chrząszcze. [In:] GŁowacińsKi Z. (ed.). Czerwona lista zwierząt ginących i zagrożonych w Polsce. Instytut Ochrony Przyrody PAN, Kraków, pp.: 74.

Romantsov P. V. 2007. A review of the leaf beetles (Coleoptera, Chrysomelidae) of St. Petersburg and Leningrad Province. Entomological Review. Pleiades Publishing, Inc. 86: 306-336.

RozNER I. 1996. An updated list of the Chrysomelidae of Hungary and the adjoining parts of the Carpathian Basin (Coleoptera). Folia Entomologica Hungarica 57: 234-260.

Silfverberg H. 2010. Subfamily Donaciinae Kirby, 1837. Pp. 354-359. [In:] Löbl I., Smetana A. (eds). Catalogue of Palaearctic Coleoptera: Chrysomeloidea. (Catalogue of Palaearctic Coleoptera). Apollo Books, Stenstrup, 924 pp.

STREJČEK J., BEzDĚK J. 2005. Chrysomelidae. [In:] FARKAČ J., KRÁl D., ŠKorpíK M. (eds). Červený seznam ohrožených druhů České republiky. Bezobratlí. AOPK ČR, Praha, pp.: 533-539.

ŚCIBIOR R., NiEOCZYM M., StRYJECKI R., KLOSKOWSKI J. 2008. Macroplea appendiculata (PANZer, 1794) (Coleoptera: Chrysomelidae: Donaciinae) - new localities of the rare chrysomelid beetle in Poland. Wiadomości Entomologiczne 27: 58-59.

TAmutis V., TAmuté B., Ferenca R. 2011. A catalogue of Lithuanian beetles (Insecta, Coleoptera). ZooKeys 121: 1-494.

VIG K. 2003. Leaf beetle fauna of the Carpathian Basin (Central Europe): historical background and perspectives (Coleoptera, Chrysomelidae). [In:] FURTH D.G. (ed.). Special topics of leaf beetle biology. Proceeding 5th International Symposium on the Chrysomelidae, Pensoft, Sofia-Moscow, pp.: 63-104. 
WARChAŁOWSKi A. 1985. Chrysomelidae - Stonkowate (Insecta: Coleoptera). Część I (część ogólna oraz podrodziny: Donaciinae, Orsodacninae, Synetinae, Zeugophorinae i Criocerinae). Fauna Poloniae, 10, Warszawa, $373 \mathrm{pp}$.

Received: July 6, 2012

Accepted: October 10, 2012 